\begin{tabular}{|c|c|c|}
\hline Beitr. Ent. & Keltern & ISSN 0005-805X \\
\hline $\mathbf{5 3}(2003) 1$ & S. $199-216$ & 31.07 .2003 \\
\hline
\end{tabular}

\title{
The Pardisomus species from Costa Rica, with descriptions of four new species and one larva
}

\section{(Coleoptera: Curculionidae: Baridinae)}

With 28 figures in the text

JENS PRENA

Summary

The neotropical weevil genus Pardisomus PASCOE is redefined based on morphological character states of Agalmatus KUSCHEL and association of six species with Pentagonia BenthaM (Rubiaceae). Procholus DESBrochers, Anambates CASEY, Piazambates VOSS and Agalmatus are new synonyms of Pardisomus. New combinations with Pardisomus are 1) from Agalmatus: P. brasiliensis (KUSCHEL), P. geniculatus (HUSTACHE), $P$. nigritarsis (KUSCHEL), P. panamensis (KUSCHEL); 2) from Embates: $P$. cleroides (CHAMPION); 3) from Lydamis: P. squamipes (KIRSCH); 4) from Peridinetus: P. rufescens (Hustache); 5) from Piazambates: P. piazuroides (VOss); and 6) from Procholus: P. biplagiatus (DesBrochers). Four new species of Pardisomus are described from Costa Rica: $P$. albescens, $P$. amotus, $P$. byrrus and $P$. suffuscus. The larva of putative $P$. biplagiatus is described for the first time.

\section{Zusammenfassung}

Die neotropische Rüsselkäfergattung Pardisomus PASCOE wird neu definiert auf der Grundlage morphologischer Merkmale von Agalmatus KUSCHEL und der Vergemeinschaftung von sechs Arten mit Pentagonia Bentham (Rubiaceae). Procholus Desbrochers, Anambates CASEY, Piazambates Voss und Agalmatus sind neue Synonyme von Pardisomus. Neu kombiniert werden mit Pardisomus 1) aus Agalmatus: P. brasiliensis (KusCHEL), P. geniculatus (HUSTACHE), P. nigritarsis (KUSCHEL), P. panamensis (KUSCHEL); 2) aus Embates: P. cleroides (CHAMPION); 3) aus Lydamis. P. squamipes (KIRSCH); 4) aus Peridinetus: P. rufescens (HUSTACHE); 5) aus Piazambates: $P$. piazuroides (Voss); und 6) aus Procbolus: $P$. biplagiatus (Desbrochers). Aus Costa Rica werden vier neue Pardisomus-Arten beschrieben: $P$. albescens, $P$. amotus, $P$. byrrus und $P$. suffuscus. Die Larve von mutmaßlichen $P$. biplagiatus wird erstmalig beschrieben.

\section{Key Words}

weevils, taxonomy, new species, Pentagonia, Neotropics

\section{Introduction}

The neotropical region is inhabited by numerous species of baridine weevils with more or less developed vestiture of minute scales, dentate femora and concealed pygidium. The current system for their classification is based largely on trivial character states, and 
little is known about their phylogenetic relationships. Recent field work carried out in Costa Rica provided now new information toward a better understanding of one group of those weevils. While the majority of species referred to above is associated with plants in Annonaceae and Piperaceae, a number of medium-sized species with triangularly shaped body were found to be associated with plants in Pentagonia (Rubiaceae). This group includes several weevils of equivocal systematic assignment, which have been placed in three different tribes. The general geographic distribution of the weevils matches with that of Pentagonia, and the plant associations observed in Costa Rica and Panama (for $P$. geniculatus, C.W. O'BRIEN in litt.) may hold true elsewhere. Surveying the host plant genus should allow entomologists to collect specimens in other regions, from where material is scarce at present. The current paucity in collections of specimens, despite their relatively large size and often showy appearance, may result from the circumstance, that the weevils are caught rarely by standard methods such as beating, sweeping and passive trapping. In this paper, the genus Pardisomus is redefined and the Costa Rican species are revised.

Thanks are due to ROBERT J. MARQUIS and ISIDRO A. CHACÓN, who's keen field observations directed my attention to Pentagonia as a possible host plant of these weevils. Field studies at Braulio Carrillo National Park and La Selva were carried out with financial support from the US National Science Foundation within the framework of ALAS IV. Logistic support was provided by the Instituto Nacional de Biodiversidad, the Ministerio del Ambiente y Energia and the Organization for Tropical Studies. I would like to thank all participants of the ALAS project, in particular JACK LONGINO for inviting me, and the ALAS staff for doing such splendid work at ,mil setenta". Comments and suggestions by GUILlermo Kuschel, CHARLES W. O'BrIEN and ROBERT ANDERSON helped to improve the text.

\section{Material and Methods}

Approximately 235 specimens belonging to 20 species of Pardisomus, and more than 3000 specimens belonging to related genera were studied. Specimens were obtained on loan from the following collections: ALAS, Arthropod Collection of La Selva Biological Station, Puerto Viejo, Costa Rica (D. BRENES); AMNH, American Museum of Natural History, New York (L. HERMAN JR.); BMNH, The Natural History Museum (British Museum), London (C. LYAL); CHAH, HENRY A. HESPENHEIDE personal collection, Los Angeles; CMNC, Canadian Museum of Nature, Ottawa (R. ANDERSON); CWOB, CHARLES W. O'BRIEN personal collection, Tallahassee; DEIC, Deutsches Entomologisches Institut, Eberswalde (L. BEHNE, L. ZERCHE); FOEC, FrODE OEDEGAARD personal collection, Trondheim; HAHC, HENRY \& ANNE HOWDEN personal collection, Ottawa; HPSC, HENRY P. STOCKWELL personal collection, Panama; INBC, Instituto Nacional de Biodiversidad, Santo Domingo de Heredia, Costa Rica (A. Solf́s); MNHN, Museum National d'Histoire Naturelle, Paris (H. PERRIN); SMTD, Staatliches Museum für Tierkunde Dresden (R. KRAUSE); TAMU, Texas A\&M University, College Station (E. RILEY); USNM, National Museum of Natural History, Washington D.C. (J. PAKALUK, A. KONSTANTINOv); ZMHB, Museum für Naturkunde, Berlin (J. SCHULZE, M. UHLIG). The codens are used to tefer to the collections in the text. JPPC refers to my personal collection located in Rostock.

Measurements of length were made with an ocular micrometer in a dissecting microscope as follows: total length, from anterior margin of eye to elytral apex in dorsal view; pronotal length, longest dorsal extension in lateral view; elytral length, longest dotsal extension, i.e. between humeri and elytral tip along suture; length of rostrum, straight distance from apex (without mandibles) to anterior matgin of eye at middle of rostrum in lateral view; apical portion of rostrum, straight distance from apex (without mandibles) to point of antennal insertion in lateral view.

Larvae were prepared for drawing as described in MAY (1994), and her larval terminology is used. The identification of the larvae is based on their association with adult specimens at two different sites in $\mathrm{La}$ Selva, their size (synchoreously occurring $P$. cleroides should be smaller) and comparison with three species 
of Embates and one species of $P_{\text {eridinetus }}$ (personal unpublished data). Drawings were made using the grid of an occular micrometer. Geographical data were plotted by means of the program PanMap (Bremen University). Shore lines were provided by the British Oceanographic Data Center and elevations by the EROS data center of the United States Geological Survey.

\section{Pardisomus Pascoe}

Pardisomus PASCOE, 1889: 327. Type species Centrinus guttatus PASCOE (by original designation).

Pseudocbolus Desbrochers, 1906: 366 (not LACORDAIRE, 1866). Type species Pseudocholus biplagiatus DESBROCHERS (by indication).

Procholus DeSBRochers, 1907: 6. Replacement name for Pseudocholus DESBROCHERS, 1906. New synonymy.

Pseudambates CHAMPION, 1907: 171. Replacement name for Pseudocbolus DeSBRochers, 1906.

Spbalerocbolus HELler, 1908: 59. Replacement name for Pseudocholus DesBrochers, 1906.

Anambates CASEY, 1922: 7. Type species Ambates cleroides CHAMPION (by original designation). New synonymy.

Piazambates Voss, 1954: 304. Type species Piazanbates piąuroides Voss (by indication). New synonymy. Agalmatus KuSCHEd, 1958: 751. Type species Agalmatus panamensis KusCHEL (by original designation).

New synonymy.

Recognition. Pardisomus includes triangularly shaped species (figs. 2, 4-6) of 5-11 mm length with dentate femora, concealed pygidium and short antennal club. The pronotum undergoes sexual dimorphism in the majority of species (i.e., larger in males). The procoxae may be contiguous, slightly (though appreciably) separated from each other, or either depending on sex. Adults and larvae are associated with plants in Pentagonia BENTHAM (Rubiaceae).

Definition. Body moderately large to large (for Baridinae), total length $5-11 \mathrm{~mm}$, elytra subtriangular, humeri prominent, pygidium covered by elytral apices, all femora equally dentate ventrally, procoxae contiguous or slightly separated, prosternal canal obsolete, antennal club compact, short, all segments pubescent (fig. 3), elytral interstriae finely costate or convex apically, tarsal claws flat and subconnate at base, tibiae nearly straight and parallel-sided, body of aedeagus short, approximately $2 \mathrm{x}$ longer than wide, apex blunt, membranous laterodistally, apical portion more or less rectangular to long axis in lateral view, basal portion sigmoid (fig. 9), apodemes 2.5-2.7x longer than body of aedeagus, gonopore distal, ejaculatory duct inside internal sac (aedeagal flagellum) sclerotized, filiform, approximately as long as apodemes, basal sclerite short, attached to internal sac from outside, lateral arms of male sternite 9 asymmetric (fig. 11), spermathecal duct approximately as long as bursa and vagina combined, inserted in distal forth of bursa, stylus with 6 setae.

Discussion. A useful morphological concept for the genus was suggested by KUSCHEL (1958). However, he was not aware of several senior names, which is not surprising considering the sparse material present in the collections and the spectrum of opinions brought forward concerning their systematic position. Our hostplant data not only support KUSCHEL'S concept but provide a completely new criterion for the classification of these weevils. My decision to adopt a relatively broad approach and to include Embates cleroides in Pardisomus needs to be explained. That species and the closely related $P$. amotus may appear at a first glance somewhat isolated in the Middle American fauna through their gibbous pronotum. However, various degrees of gibbosity occur generally 
in male Pardisomus, and the shape of the pronotum is intermediate in the Brazilian Ambates nobilis FAUST in litt. (not FAUST 1892; in DEIC, SMTD, ZMHB). All these species agree well in structural details of the male genitalia. The only exception occurs in $P$. amotus, where the base of the aedeagal flagellum is organized differently (fig. 18), but all other character states concur with the concept of the genus. It can be said generally, that the basal sclerite is relatively distinctive for the various species of Pardisomus, while the shape of the aedeagus exhibits remarkable uniformity. For this reason, genital structures are illustrated only for one species, i.e. P. amotus, while the basal sclerite is illustrated for all species treated in the text.

\section{Species included in Pardisomus:}

$P$. albescens sp. $\mathrm{n}$.

P. amotus sp. $\mathbf{n}$.

P. biplagiatus (DESBROCHERS, 1906): 366 (Pseudocholus), comb. $\mathbf{n}$.

P. brasiliensis (KUSCHEL, 1958): 754 (Agalmatus), comb. $\mathbf{n}$.

P. byrrus sp. $\mathrm{n}$.

P. cleroides (CHAMPION, 1907): 170 (Ambates), comb. $\mathbf{n}$.

P. geniculatus (HUSTACHE, 1950): 12 (Peridinetus), comb. $\mathbf{n}$.

P. guttatus (PASCOE, 1889): 327 (Centrinus)

P. multiguttatus HUSTACHE, 1950: 26

P. nigritarsis (KUSCHEL, 1958): 756 (Agalmatus), comb. n.

P. panamensis (KUSCHEL, 1958): 752 (Agalmatus), comb. n.

P. piazuroides (Voss, 1954): 305 (Piarambates), comb. $\mathbf{n}$.

P. rufescens (HUSTACHE, 1950): 12 (Peridinetus), comb. $\mathbf{n}$.

P. squamipes (KIRSCH, 1875): 267 (Scambus), comb. n.

P. suffuscus sp. n.

Key to the Costa Rican species of Pardisomus

$1 \quad$ Elytra with well-defined color pattern ..............................................................

1' Elytra with irregular clusters of light-colored scales or ill-defined fasciae .......... 4

2 Pronotum and elytra glabrous, yellow scales condensed in two elytral fasciae....

biplagiatus

2' Pronotum and elytra densely covered with scales, vestiture of black, red, ochreous and white scales

3 Body stouter, white elytral fascia curved basally on interstria 2 (fig. 6); Pacific watershed in Costa Rica and western Panama. cleroides

3' Body more slender, white elytral fascia not notably curved on interstria 2; Atlantic watershed in Costa Rica amotus 
4 Size 7.5-8.1 mm, pronotal disk finely rugose, procoxae slightly separated, integument castaneous, interstria 2 costate between middle and apex .............. byrrus

4' Size 4.9-6.6 mm, pronotal disk finely punctate, intervals smooth, procoxae contiguous, integument castaneous or black, interstria 2 finely costate apically ........5

5 Integument castaneous, basal vestiture of cupreous hairs intermixed with few small clusters of white scales, interstriae costate in apical third suffuscus

5' Integument black, white scales condensed on flanks and in ill-defined elytral fasciae, odd-numbered interstriae tumid near preapical callus

albescens

\section{Pardisomus byrtus sp. $\mathrm{n}$.}

Figs. 1-3, 14, 28

Holotype male, Costa Rica, labeled: „Puntarenas. Costa Rica/ P.de Osa.Rancho Quemado/ 29 mayo de 1988/ A.Solis", INBio code CRI001 044476, my red label „HOLOTYPE/ Pardisomus/ byrrus Prena/ Prena det. 2002”, dissected (INBC). Paratypes 4 (1 male, 3 females), labeled: „CR Puntarenas/ Golfito. Refugio/ de Fauna.Sil./ 4 Setiembre 1986/ Col: J. Corrales”, CRI000 057698, male (JPPC); „COSTA RICA, Prov. Puntarenas, Fila/ Cruces, Fca. Ilama. 1200m. 6 MAY/ 1996. I. A. Chacón./ L_S_303100_568250 \#8237”, CRI002 448037, female (CMNC); „Rancho Quemado, 200m,/ Peninsula de Osa, Prov./ Puntarenas, Costa Rica/ Jul 1992, M.Segura/ L-S 292500, 511000”, CRI000 730977, female (CWOB); „Rancho Quemado, Pen. de Osa, Prov./ Punta, COSTA RICA. 200m. 14-30 Ago/ 1993. A. Marín,/ L S 292500_511000 \#2303", CRI001 156707, female (INBC).

Description. Habitus: figs. 1 and 2, total length 7.5-8.1 mm (mean=7.8, $\mathrm{n}=5$ ). Head: castaneous, punctate, white to ochreous scales on frons, frontal fovea shallow and elongate, transition between head and rostrum very slightly depressed; rostrum castaneous, subcylindrical, curved, punctate, scales minute, dorsomedian carina present (males) or not (females), rostral length males 0.96-1.00x $(\mathrm{n}=2)$, females 1.11-1.15x (mean $=1.13, \mathrm{n}=3$ ) pronotal length, portion distal to antennal insertion males $0.33 \mathrm{x}$ $(\mathrm{n}=2)$, females $0.38-0.40 \mathrm{x}$ (mean $=0.39, \mathrm{n}=3$ ) total rostral length; antenna castaneous, funicular segment 2 longer than 1, antennal scrobe gradually descending, reaching ventral margin of rostrum before eye. Pronotum: castaneous, scales white to ochreous, sparse on disk; pronotal length males $0.80-0.81 \mathrm{x}(\mathrm{n}=2)$, females $0.71-0.74 \mathrm{x}$ (mean $=0.72$, $\mathrm{n}=3$ ) maximum width; pronotal width males $0.74-0.77 \mathrm{x}(\mathrm{n}=2)$, females $0.74-0.75 \mathrm{x}$ $(m e a n=0.74, n=3$ ) greatest elytral width; sides rounded from base to front, anterior portion tubulate, disk convex, punctate, intervals rugose, dorsomedian carina absent. Elytra: castaneous, scales white to ochreous in irregularly arranged small clusters; elytral length 1.22-1.30x (mean $=1.24, \mathrm{n}=5$ ) width at humeri, sides gradually converging behind humeri, preapical callus moderately developed, striae distinct, interstriae broad, 2 costate in apical half, 3-6 costate in apical third, 7-9 costate throughout. Legs: rufous, femora moderately expanded dorsoventrally, femoral tooth distinct, tibial margin ventrodistally with cluster of yellow hairs, males with fringe of hairs on venter of femora and tibiae. Venter: castaneous, beige scales condensed on prosternum and flanks; procoxae slightly separated in both sexes. Male genitalia: anterior portion of aedeagus moderately curved 
ventrad, apodemes $2.7 x$ longer than body of aedeagus, aedeagalflagellum slightly longer than apodemes, transition to basal portion abrupt, basal sclerite curved irregularly (fig. 14). Plant association. Not known.

Distribution. The species occurs on the Pacific side of the Cordillera de Talamanca in Costa Rica (fig. 28) and possibly in adjacent Panama. Four of the specimens were collected in the lowlands around $200 \mathrm{~m}$ elevation, one specimen was collected in a premontane habitat at $1200 \mathrm{~m}$.

Specific epithet. The name is a Latin adjective meaning reddish brown.
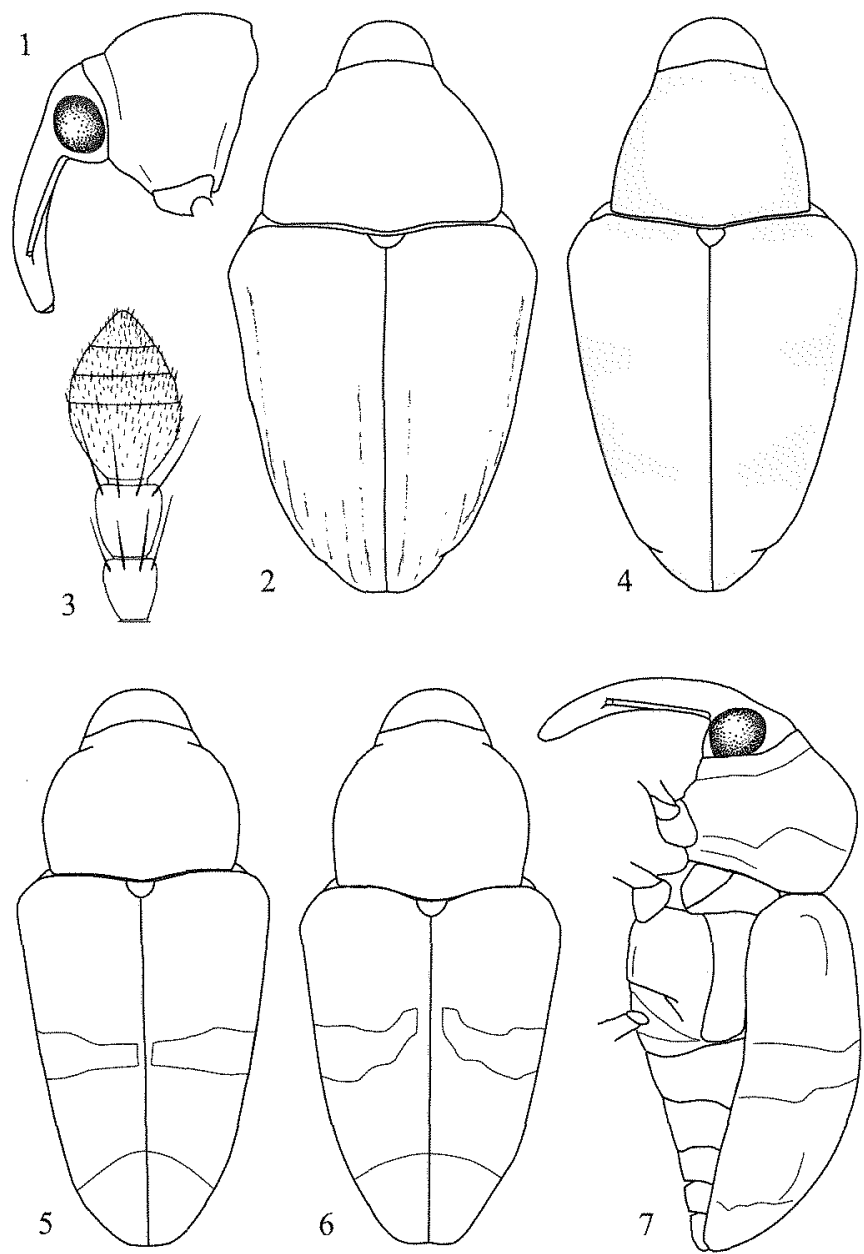

Figs. 1-7. Pardisomus. P. byrrus, 1) head and prothorax, lateral, 2) habitus, dorsal, 3) antenna, distal segements; $P$. albescens, 4) habitus, dorsal; $P$. amotus, 5) habitus, dorsal; $P$. cleroides, 6) habitus, dorsal, 7) habitus, lateral; all males 
Discussion. Pardisomus byrrus belongs to a complex of South American species, with closest affinity to the Peruvian $P$. rufescens. The latter species has a much longer rostrum, lacks the distinct costation of elytral interstria 2 , and differs in color and vestiture. Other members of this complex are $P$. geniculatus, $P$. guttatus, $P$. multiguttatus and $P$. nigritarsis.

\section{Pardisomus biplagiatus (DESBROCHERs), comb. n.}

Figs. 15, 20-28

Psetdocholus biplagiatus DESBROCHERS, 1906: 366. Lectotype, sex not determined, Costa Rica, designated here, labeled: „collection Schild-Burgdorf, Costa Rica, San Carlos”, handwritten „n.sp.”, green label "Museum Paris, 1955, coll. A. Clerc”, „LECTOTYPE/ Pseudocholus/ biplagiatus Desbr./ Prena desig. 2002"; "Pardisomus/ biplagiatus (Desbr.)/ Prena det. 2002" (MNHN). Paralectotypes, 2, designated here, labeled: „collection Schild-Burgdorf, Costa Rica, San Carlos”, green label „Museum Paris, 1955, coll. A. Clerc”, "paralectotype” (MNHN); „collection Schild-Burgdorf, Costa Rica, San Carlos", "Collection Dr A. Clerc", „Museum Paris, 1949, Col. A. HustachE”, "paralectotype” (MNHN).

Procbolus biplagiatus (DEsBrochers). DesBrochers, 1907: 6; BLACKWELDER, 1947 (cat.); O'BrIEN \& WIBMER, 1982 (cat.); MARQUIS, 1991: 181 (plant association).

Pseudambates biplagiatus (DESBROCHERS). CHAMPION, 1907: 171.

Sphalerocholus biplagiatus (DESBROCHERS). HELLER, 1908: 59.

Redescription. Habitus: figured in CHAMPION (1906-09, plate 9), total length 7.5$10.1 \mathrm{~mm}$ (mean=8.9, $\mathrm{n}=33$ ). Head: black, nude, finely punctate, frontal fovea shallow and elongate, transition between head and rostrum very slightly depressed; rostrum black, subcylindrical, slightly curved, finely punctate (apically very subtle in females), nude, dorsomedian carina present (males) or not (females), rostral length males 1.061.14x (mean $=1.10, \mathrm{n}=18)$, females $1.15-1.31 \mathrm{x}$ (mean $=1.24, \mathrm{n}=13$ ) pronotal length, portion distal to antennal insertion males $0.36-0.40 \mathrm{x}$ (mean $=0.38, \mathrm{n}=18$ ), females 0.35 $0.42 \mathrm{x}$ (mean $=0.40, \mathrm{n}=13$ ) total rostral length; antenna piceous to black, funicular segment 2 longer than 1, antennal scrobe gradually descending, reaching ventral margin of rostrum before eye. Pronotum: black, nude, yellow scales at flank; pronotal length males $0.79-0.84 \mathrm{x}($ mean $=0.81, \mathrm{n}=18)$, females $0.76-0.81 \mathrm{x}($ mean $=0.79, \mathrm{n}=14)$ maximum width; pronotal width males $0.77-0.80 \mathrm{x}$ (mean $=0.78, \mathrm{n}=18$ ), females $0.72-0.77 \mathrm{x}$ (mean $=0.74, \mathrm{n}=14$ ) greatest elytral width; sides rounded in basal third, then gradually converging and tubulate in front, disk convex, finely punctate, intervals glabrous, dorsomedian carina absent. Elytra: black, scales yellow in curved post-humeral and straight subapical fasciae; elytral length 1.22-1.29x (mean=1.26, $\mathrm{n}=32$ ) width at humeri, sides gradually converging behind humeri, preapical callus moderately developed, striae distinct, interstriae broad, increasingly convex apically but not clearly costate. Legs: black, femora moderately expanded dorsoventrally, femoral tooth distinct, tibial margin ventrodistally with cluster of cupreous hairs. Venter: black, yellow scales on portions of prosternum, metepisternum, metasternum, sternite 4 (second visible sternite); procoxae contiguous in both sexes. Male genitalia: anterior portion of aedeagus moderately curved ventrad, apodemes ca. $2.5 \mathrm{x}$ longer than body of aedeagus, aedeagal flagellum slightly shorter than apodemes, transition to basal portion abrupt, basal sclerite curved irregularly (fig. 15). 
Description of late-instar larva. Habitus: $15 \mathrm{~mm}$ long, $4 \mathrm{~mm}$ wide (measurements refer to the largest of three specimens studied), slightly curved, widest at abdominal segments 2 and 3 (fig. 20); abdominal segment 8 modified to oblique, concave disk (fig. 21); cuticle finely asperate, creamy white; setae light brown, translucent, inconspicuous. Head: slightly retracted, amber-brown, without epicranial ridge (cf. MAY 1994, p. 533); slightly wider than long, width $1.7 \mathrm{~mm}$, sides evenly rounded (fig. 22); both pairs of stemmata distinct (faded when slide mounted); accessory appendage of basal antennal segment conical, $2 x$ longer than wide (fig. 23); frontal suture distinct, endocarina obsolete and short; 5 pairs of frontal setae, setae $1-3$ very short, seta 4 approximately $2 / 3$ length of seta 5; 5 pairs of dorsal epicranial setae, seta 4 very short; 2 pairs of long lateral epicranial setae; clypeus $2.7 \mathrm{x}$ wider than long, subconical, clypeal setae 1 and 2 subequal in length (fig. 26); anterior margin of labrum slightly trilobate, 3 pairs of labral setae, seta 1 longest; labral rods (tormae) Y-shaped, hypopharyngal lining with 2 pairs of short anteromedian setae, 3 pairs of anterolateral setae 1.5-2x longer than anteromedian setae, 3 pairs of short median setae, and 1 pair of sensilli between proximal pair of median setae (fig. 27); mandible with two distinct apical teeth of equal size, two setae (fig. 24); maxilla with palpus 2-segmented, basal segment with short seta and two sensilli, mala with 3 moderately long and 2 short ventral setae and row of 7 dorsal setae of subequal size (fig. 25); labium with palpus 2 -segmented, premental sclerite tridentate, basal process slender and elongate, with flanks depressed and with elongate sclerite, postlabial seta 2 much longer than setae 1 and 3 (fig. 25). Pronotum: light brown, 5 pairs of long and 3 pairs of short setae; spiracle bicameral, air-tubes annulated, arranged vertically; 1 pair of prodorsal and 4 pairs of postdorsal setae on meso- and metathorax, 1 short spiracular (alar) seta, 1 long epipleural seta, 1 long pleural seta, 2 long and 4 short pedal setae, 1 pair of sternal setae. Abdomen: spiracles bicameral, air-tubes annulated, small and horizontal at segments 1-7, pair 8 much larger, arranged vertically and moved dorsad onto disk formed by segment 8 (fig. 21); segments 1-7 with 1 pair of short prodorsal and 2 pairs of long postdorsal setae, 1 short spiracular (alar) seta, 2 epipleural setae of unequal length, 2 pleural setae of unequal length, 1 long pedal seta, 2 pairs of short sternal setae; segment 8 modified to concave disk, slightly pigmented, not sclerotized, 4 pairs of long and 2 pairs of short setae along periphery, 1 pair of long setae in center (fig. 21); anus ventral.

Material examined. A total of 92 adult weevils ( 27 males, 18 females, 47 not sexed) and three larvae were studied from the following locations (fig. 28): COSTA RICA. Without collecting site: (MNHN 8). Alajuela: San Carlos, $800 \mathrm{~m}$ (BMNH, MNHN 3, USNM). Limón: $30 \mathrm{~km}$ N Cariari, Cerro Cocorí, Finca de E. Rojas, $150 \mathrm{~m}$ (INBC 14, AMNH); Barra del Colorado, Rio Sardinas, $10 \mathrm{~m}$ (INBC 2); Sector Cedrales de la Rita, $3 \mathrm{~km}$ N Puente Rio Suerte, Ruta Puerto Lindo, $10 \mathrm{~m}$ (INBC 3); P.N. Tortuguero, 10$100 \mathrm{~m}$ (INBC 2, JPPC, USNM); Guápiles, 300 m (HPSC, USNM 2); Cabo Blanco, 300 m (USNM); Rio Reventazon, Hamburg Farm, 50 m (BMNH, USNM); R.B. Hitoy Cerere, $100 \mathrm{~m}$ (INBC, JPPC). Cartago: Tres Ríos, $1300 \mathrm{~m}$ (USNM 2). Heredia: P.N. Braulio Carrillo, Est. Magsasay, $200 \mathrm{~m}$ (INBC 3), Transect near Rio Peje, $450 \mathrm{~m}$ (JPPC 2); Est. Biol. La Selva, Puerto Viejo, $150 \mathrm{~m}$ (ALAS 10, CHAH 3, CMNC, CWOB, JPPC $16+3$ larvae, TAMU, USNM 8); Puerto Viejo $10 \mathrm{~km} \mathrm{~W} \mathrm{(HAHC).}$

Plant association. Pardisomus biplagiatus is associated with Pentagonia donnell-smithii (approximately 25 own observations), and occurs primarily in semi-open, drained habitats on plants less than $2 \mathrm{~m}$ tall. The larvae tunnel the apical portion of the stem including 
the basal portion of the petioles. A single record from Calyptrogyne sarapiquensis (Arecaceae), in the ALAS collection, probably refers to an observation made on a specimen of Cholus.

Distribution. The species occurs in secondary rain forests of the Atlantic side of the Cordillera Central in Costa Rica (fig. 28), and may be expected in Nicaragua. Collections from premontane habitats, such as San Carlos and Tres Ríos, have not been made since the early 1900 s.

Discussion. Dr. PERRIN was very helpful in the recognition of the type series housed in the Museum Paris. DESBROCHERS must have seen at least two specimens, because he gave a size range for the species. Many of DESBROCHERS' exotic specimens went in the CLERC collection, from where HUSTACHE obtained some specimens on exchange. In these two collections (now in MNHN) are nine specimens of $P$. biplagiatus, three with the collecting site San Carlos and reference to the DESBROCHERS collection. One of those three specimens has a handwritten label „n. sp.", and is designated here as lectotype. The other two specimens are designated here as paralectotypes.

The color pattern of $P$. biplagiatus has deluded more than one entomologist, who felt it was related to certain species of Embates and Peridinetus. CHAMPION (1907) gave a good generic diagnosis based on this species, with criteria similar to those used by KUSCHEL (1958), but failed to relate the species to the differently colored, but morphologically similar $P$. guttatus (PASCOE). No attempt is made here to interpret any larval character states, because the sparse data available is insufficient for generalization. The conspicuous modification of the caudal segments occurs in several species of Bagous and Neobydronomus (MAY, 1994), but has not been reported for species in Baridinae. However, it is present in at least three species of Embates (where the apical portion is strongly sclerotized) and in at least one species of Peridinetus (personal unpublished data). I suspect that the caudal „shovel” is employed for cleaning the larval tunnel of debris.

\section{Pardisomus albescens sp. $\mathbf{n}$.}

Figs. 4, 16, 28

Holotype male, COSTA RICA, labeled: ,COSTA RICA, Prov. Puntarenas, Fila Cruces, Entrada de los Atunes./ 1200m. 4 MAY 1996. I. A./ Chacon. L_S_306000_571100/ \#8236“, INBIO CRI002 496266, my red label „HOLOTYPE/ Pardisomus/ albescens Prena/ Prena det. 2002", dissected (INBC). Paratypes 24 (16 males, 8 females), labeled: „COSTA RICA, Prov. Puntarenas, Fila/ Cruces, Fca. Ilama. 1200m. 1 ABR/ 1996. I. A. Chacon./ L_S_303100_568250 \#8255“, INBIO CRI002 455196, male (INBC); „COSTA RICA, Prov. Puntarenas, Fila/ Cruces, Fca. Ilama. 1200m. 6 MAY/ 1996. I. A. Chacon./ L_S_303100_568250 \#8237“, INBIO CRI002 448044, female (INBC); „COSTA RICA, Prov. Puntarenas, Fila/ Cruces, Fca Fabio Sandoval. 1200m./ 23 MAY 1995. I. A. Chacon./ L_S_306000_571100 \#8266“, INBIO CRI002 470440, male (CMNC); „Est. Pittier, Prov. Punta, COSTA RICA./16 NOV-9 DIC 1995. E./ Navarro, Interseccion con carrońa de/ Pescado L_S_330900_577400 \#6447“" INBIO CRI002 330933, male (INBC); „Est. Pittier, Sendero Altamira, 900m/ NO. de la Estacion, Puntarenas, Costa/ Rica.1740m. 9-11 ABR 1996. A. M./ Maroto, L_S_331500_576800/ \#7524“, INBIO CRI002 376313, male (INBC); „COSTA RICA: Prov. Heredia:/ 16km

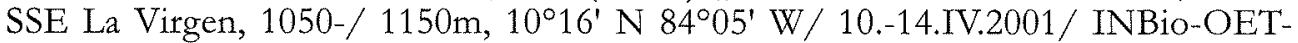


ALAS transect”, ,handcollecting/ leg. Jens Prena”, INB0003209958, male (JPPC); same label, INB0003209927, male (JPPC); same label, INB0003209928, female (ALAS); same label except „10.-14.III.2001”, INB0003209904, male (TAMU); same label, INB0003209905, male (ALAS); same label, INB0003209906, female (JPPC); „COSTA RICA, S.J. Zur-/ qui de Moravia, 1600m./ X-1995, malaise/ trap, Hanson \& Godoy", „C.W.O'BRIEN/ COLLECTION”, males (CWOB 2); „R. San Lorenzo, 1050m,/ R.F. Cord.Guanacaste/ (Tenorio) ,Prov. Guan./ COSTA RICA. C./ Alvarado, Jun 1991,/ L-N-287800,427600“, INBIO CRI000 668661, male (INBC); same label, INBIO CRI000 365018, female (INBC); „R. Sn Lorenzo, 1050m,/ Tierras Morenas, R.F./ Cord.Guanacaste, Prov./ Guan. COSTA RICA./ C.Alvarado, Oct 1991,/ L-N287800,427600“, INBIO CRI000 536773, female (INBC); „R. Sn Lorenzo, 1050m,/ Tierras Morenas, R.F./ Cord.Guanacaste, Prov./ Guan. COSTA RICA./ C.Alvarado, Dic 1991,/ L-N-287800,427600“, INBIO CRI000 354428, male (USNM); same label, INBIO CRI000 354431, female (MNHN); same label, INBIO CRI000 354430, female (INBC); same label, INBIO CRI000 354429, female (INBC); „Rio San Lorenzo, $1050 \mathrm{~m}$,/ Tierras Morenas, Z.P./ Tenorio, Prov.Guanacaste/ Costa Rica, M.Segura/ 23 mar a 21 abr 1992/ L-N 287800,427600“, INBIO CRI000 422494, male (BMNH); „Rio San Lorenzo, 1050m,/ Tierras Morenas, Z.P./ Tenorio, Prov.Guanacaste/ Costa Rica, Abr 1992/ F.Quesada/ L-N 287800,427600“, INBIO CRI000 868145, male (INBC); ,Rio San Lorenzo, 1050m,/ Tierras Morenas, Z.P./ Tenorio, Prov.Guanacaste/ Costa Rica, Oct 1992/ G.Rodriguez/ L-N 287800,427600“, INBIO CRI000 836584, male (INBC); same label, INBIO CRI000 836582, male (INBC).

Description. Habitus: fig. 4, total length 4.9-6.6 $\mathrm{mm}$ (mean=5.8, $\mathrm{n}=25)$. Head: piceous to black, punctate, few white scales on frons, frontal fovea minute, transition between head and rostrum slightly depressed; rostrum piceous to black, subcylindrical, curved, punctate, setiform scales inconspicuous, dorsomedially tumid (males) or not (females), rostral length males 1.11-1.30x (mean=1.17, $\mathrm{n}=17$ ), females 1.26-1.41x (mean=1.32, $\mathrm{n}=8$ ) pronotal length, portion distal to antennal insertion males $0.27-0.37 \mathrm{x}$ (mean $=0.32$, $\mathrm{n}=17$ ), females $0.35-0.40 \mathrm{x}$ (mean $=0.37, \mathrm{n}=8$ ) total rostral length; antenna piceous to black, funicular segment 2 longer than 1 , antennal scrobe gradually descending, reaching ventral margin of rostrum before eye. Pronotum: piceous to black, disk nude or with inconspicuous setiform scales, scales white (rarely with ochreous tinge) and ovate elsewhere; pronotal length males 0.82-0.88x (mean=0.85, $\mathrm{n}=17$ ), females $0.79-0.84 \mathrm{x}$ (mean $=0.81, \mathrm{n}=8$ ) maximum width; pronotal width males $0.67-0.71 \mathrm{x}$ (mean $=0.69$, $\mathrm{n}=17$ ), females $0.66-0.69 \mathrm{x}$ (mean $=0.68, \mathrm{n}=8$ ) greatest elytral width; sides subparallel or slightly converging in basal third, then strongly rounded and tubulate in front, disk convex, finely punctate, intervals smooth, dorsomedian tumidity absent. Elytra: piceous to black, basic vestiture of inconspicuous setiform cupreous scales, white (rarely with ochreous tinge) ovate scales predominant at base, apex and in ill-defined fasciae (fig. 4); elytral length $1.33-1.43 \mathrm{x}$ (mean $=1.37, \mathrm{n}=25$ ) width at humeri, sides gradually converging behind humeri, preapical callus weakly developed, striae distinct (occasionally obsolete on disk), interstriae broad, odd-numbered conspicuously raised near preapical callus. Legs: rufous, tarsi piceous, femora moderately expanded dorsoventrally, femoral tooth rather small and sharp, tibial margin ventrally with inconspicuous fringe of widely spaced hairs, ventrodistally with cluster of cupreous hairs. Venter: piceous to black, white scales condensed on prosternum and flank; procoxae contiguous in both sexes. 
Male genitalia: anterior portion of aedeagus moderately curved ventrad, apodemes 2.5-2.7x longer than body of aedeagus, aedeagal flagellum as long as apodemes, transition to basal portion abrupt, basal sclerite angular (fig. 16)

Plant association. I collected one specimen in Braulio Carrillo N.P. from a sterile specimen of Pentagonia, probably $P$. macrophylla. It fed on a leaf while sitting in a hole and exposed its flank. At the same site, I collected two specimens in the immediate vicinity of $P$. birsuta, where they rested on low vegetation after a preceding rain. In captivity one specimen nibbled from a leave of $P$. aff. macrophylla, but refused $P$. birsuta. The distal portion of the stem of some $P$. aff. macrophylla showed signs of mining activity which I would attribute to Pardisomus albescens or P. suffuscus, but there were no larvae present.

Distribution. The species is known from premontane habitats in the central mountain chains of Costa Rica, where it was collected at elevations between 900-1800 m (fig. 28).

Specific epithet. The name is a Latin participle meaning whitish.

Discussion. See under P. suffuscus.

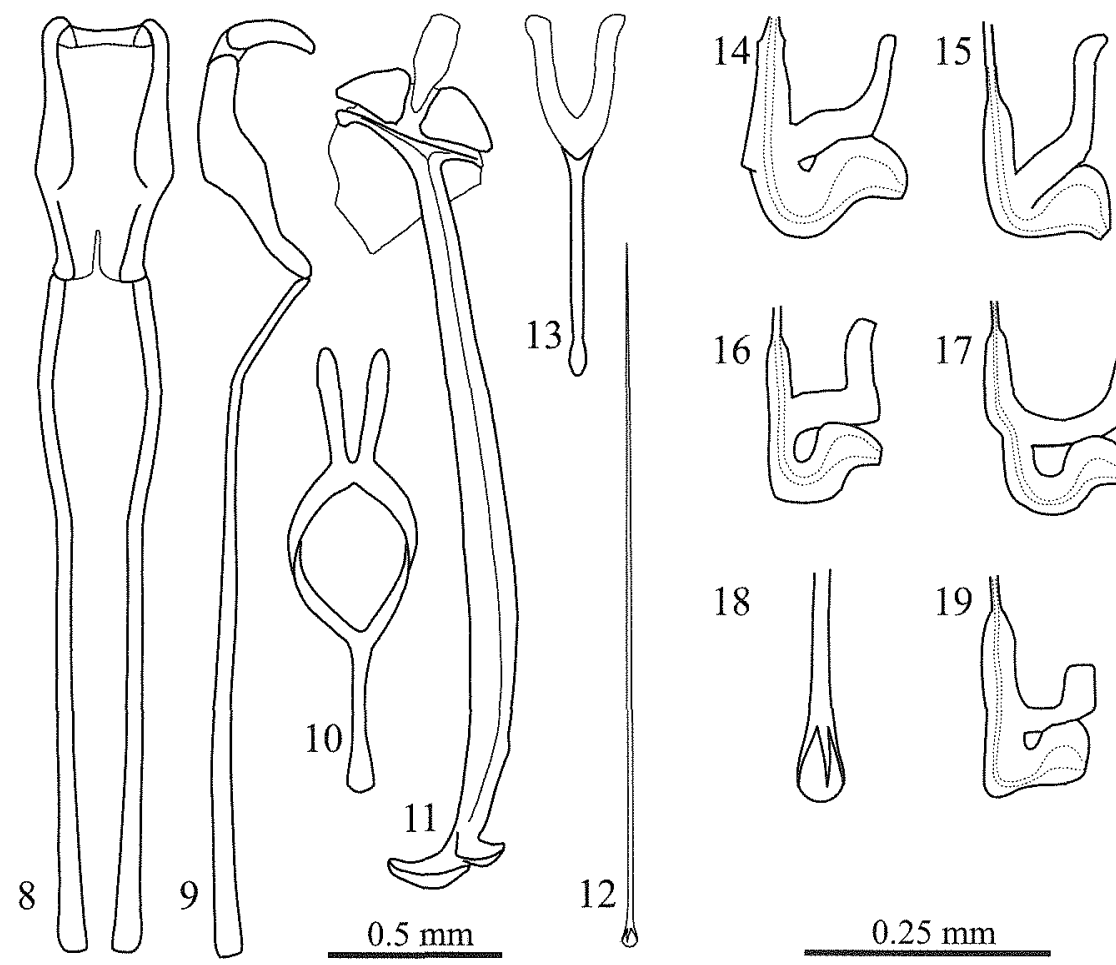

Figs. 8-19. Pardisomus. Genital structures of P. amotus, 8) aedeagus, dorsal; 9) aedeagus, lateral; 10) tegmen; 11) male sternites 8 and 9 , ventral; 12) aedeagal flagellum; 13) fernale sternite 8 (scale bar 0.5 $\mathrm{mm}$ ). Basal part of aedeagal flagellum of 14) P. byrrus; 15) P. biplagiatus; 16) $P$. albescens; 17) $P$. suffuscus; 18) P. amotus; 19) $P$. cleroides (scale bar $0.25 \mathrm{~mm}$ ) 


\section{Pardisomus suffuscus sp. $\mathrm{n}$.}

Figs. 17, 28

Holotype male, Costa Rica, labeled: „COSTA RICA: Prov. Heredia:/ 16km SSE La Virgen, $1050-/ 1150 \mathrm{~m}, 10^{\circ} 16^{\prime} \mathrm{N} 84^{\circ} 05^{\prime} \mathrm{W} / 10 .-14 . I V .2001 /$ INBio-OET-ALAS transect", ,handcollecting/ leg. Jens Prena", INBio/ALAS code INB0003209930, my red label „HOLOTYPE/ Pardisomus/ suffuscus Prena/ Prena det. 2002”, dissected (INBC). Paratypes 8 (2 males, 6 females), Costa Rica and Panama, labeled: „COSTA RICA: Prov. Heredia:/ 16km SSE La Virgen, 1050-/1150m, $10^{\circ} 16^{\prime} \mathrm{N} 84^{\circ} 05^{\prime} \mathrm{W} / 10$.- $^{\circ}$ 14.IV.2001/ INBio-OET-ALAS transect", ,handcollecting/ leg. Jens Prena", INB0003209929, male (CMNC); same label, INB0003209931, female (ALAS); same label, INB0003209932, female (TAMU); same label, INB0003209959, female (CWOB); same label, INB0003209960, male (JPPC); same label except ,10.-14.III.2001”, INB0003209903, female (BMNH); „P.N. Tapanti, Prov. Carta, COSTA RICA./ $1150 \mathrm{~m}$. Oct 1994, R. Delgado, L N/ 194000 559800 \#3269", INBIO CRI002 025130, female (INBC); ,PANAMA, B. del Toro: $4 \mathrm{~km} \mathrm{~V}$ Boquete $1700 \mathrm{~m} / \mathrm{leg} .:$ F. Oedegaard”, female (FOEC).

Description. Habitus: similar to fig. 4, total length 5.1-6.3 mm (mean=5.6, $\mathrm{n}=9)$. Head: castaneous, punctate, few ochreous scales on frons, frontal fovea minute or absent, transition between head and rostrum slightly depressed; rostrum rufous to castaneous, subcylindrical, curved, punctate, setiform scales inconspicuous, dorsomedian carina absent in both sexes, rostral length males 1.04-1.09x (mean=1.06, $\mathrm{n}=3$ ), females 1.18$1.28 \mathrm{x}$ (mean $=1.23, \mathrm{n}=6$ ) pronotal length, portion distal to antennal insertion males $0.36-0.38 \mathrm{x}$ (mean $=0.37, \mathrm{n}=3)$, females $0.34-0.41 \mathrm{x}($ mean $=0.39, \mathrm{n}=6)$ total rostral length; antenna castaneous to piceous, length of funicular segments 1 and 2 subequal, antennal scrobe gradually descending, reaching ventral margin of rostrum before eye. Pronotum: castaneous, scales cupreous and setiform on disk, white and ovate on flank and in few clusters on disk; pronotal length males $0.90 \mathrm{x}(\mathrm{n}=3)$, females $0.83-0.89 \mathrm{x}$ (mean $=0.86$, $\mathrm{n}=6$ ) maximum width; pronotal width males $0.72-0.73 x$ (mean $=0.72, \mathrm{n}=3$ ), females $0.68-0.72 \mathrm{x}$ (mean $=0.70, \mathrm{n}=6$ ) greatest elytral width; sides subparallel in basal third, then strongly rounded and tubulate in front, disk convex, finely punctate, intervals smooth, indistinct tumidity dorsomedially. Elytra: castaneous, basic vestiture of setiform cupreous scales, white ovate scales in irregular clusters and ill-defined fascia above metepisternum; elytral length 1.37-1.41x (mean $=1.39, \mathrm{n}=9$ ) width at humeri, sides gradually converging behind humeri, preapical callus weakly developed, striae distinct, interstriae broad, 2-9 costate in apical third. Legs: rufous to castaneous, tarsi piceous, femora moderately expanded dorsoventrally, femoral tooth distinct, tibial margin ventrally with inconspicuous fringe of widely spaced hairs, ventrodistally with cluster of cupreous hairs. Venter: castaneous, white scales condensed on prosternum, mesosternum, episterna and epimera; procoxae contiguous in both sexes. Male genitalia: anterior portion of aedeagus moderately curved ventrad, apodemes $2.5 x$ longer than body of aedeagus, aedeagal flagellum slightly shorter than apodemes, transition to basal portion abrupt, basal sclerite curved regularly (fig. 17).

Plant association. I collected six specimens in Braulio Carrillo N.P. from two species of Pentagonia, the one probably $P$. macropbylla, the other $P$. birsuta. Four of those specimens occurred on $P$. aff. macropbylla sitting in the angle between the stem and petioles; two of them in copula. Two specimens occurred on leaves of $P$. hirsuta, one of them apparently 
feeding. The distal portion of some stems of $P$. aff. macrophylla showed signs of mining activity, which I would attribute to either Pardisomus albescens or $P$. suffuscus, but there were no larvae present.

Distribution. The species is known only from three sites in the central mountain chains of Costa Rica and western Panama (fig. 28), and may have a similar distribution as $P$. albescens.

Specific epithet. The name is a Latin adjective for brownish.

Discussion. Pardisomus suffuscus and the closely related $P$. albescens appear to be confined to premontane habitats, and occur on both slopes of the Cordillera at elevations between 900 and $1800 \mathrm{~m}$. I found the two species coexisting in Braulio Carrillo N.P., apparently feeding on the same species of Pentagonia. However, I never saw them together on the same plant.
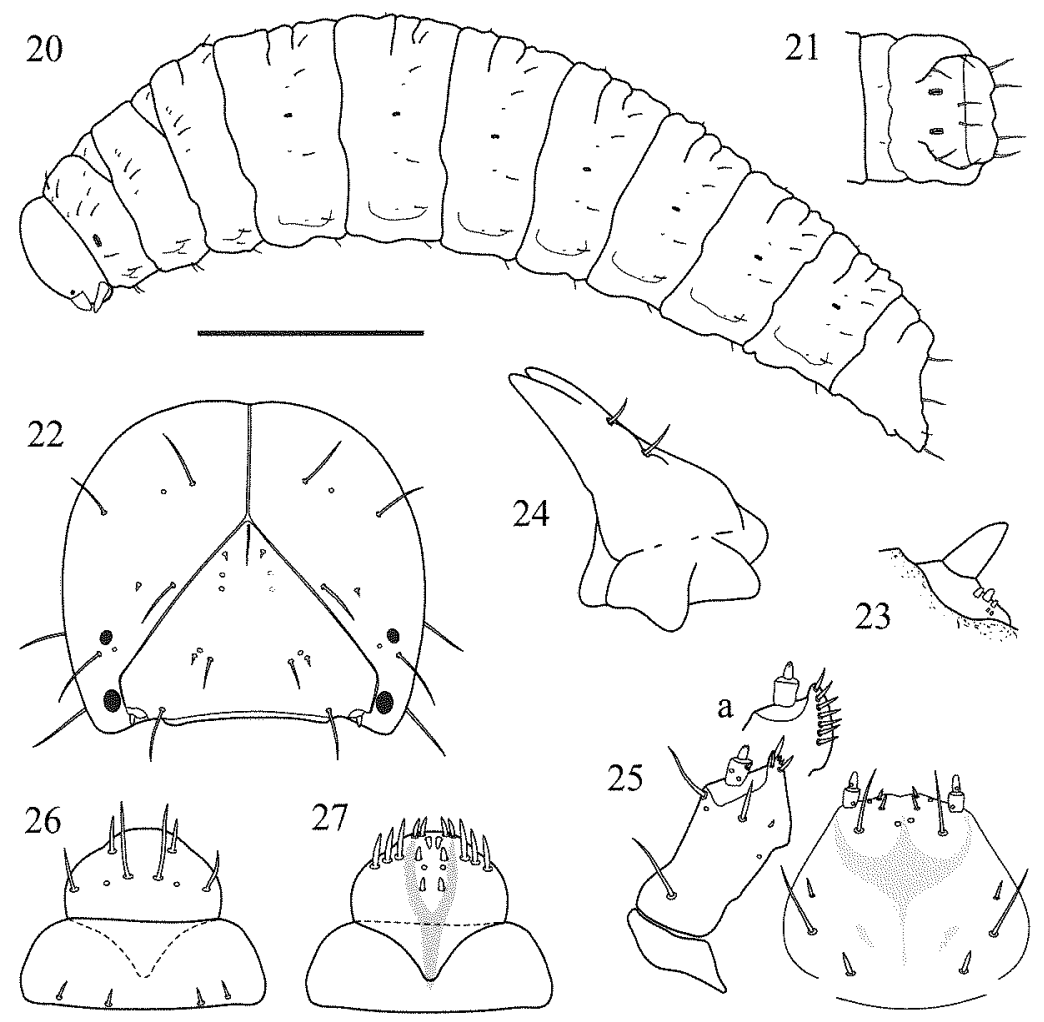

Figs, 20-27. Pardisomus. Late-instar larva of putative P. biplagiatus. 20) body, lateral; 21) distal segment, dorsal; 22) head capsule, frontal; 23) antenna; 24) right mandible, dorsal; 25) maxilla and labium, ventral (a - dorsal); 26) clypeus and labrum; 27) epipharynx. Scale bars $2 \mathrm{~mm}$ (figs. 20,21), $1 \mathrm{~mm}$ (fig. 22), $0.2 \mathrm{~mm}$ (fig. 23), $0.5 \mathrm{~mm}$ (figs. 24-27) 


\section{Pardisomus amotus sp. n.}

Figs. 5, 18, 28

Holotype male, Costa Rica, labeled: ,Sector Cerro Cocori, Fca. de E./ Rojas, 150 m, Prov. Limón,/ COSTA RICA. Abr 1993. E. Rojas./ L-N-286000, 567500", INBio code CRI001 346673, my red label „HOLOTYPE/ Pardisomus/ amotus Prena/ Prena det. 2002", dissected (INBC). Paratypes (10 males, 19 females), labeled: same locality label as holotype, INBio codes CRI001 345924, CRI001 345472, CRI001 346776, all female (INBC 3); „Sector Cocori, $30 \mathrm{~km}$ al Norte de Cariari/ Prov. Limón,/ COSTA RICA. 100 m. Oct/ 1994, E. Rojas, L N 286000_567500 \#/3313", CRI002 125976 , male, dissected (CWOB); „Sector Cocori, $30 \mathrm{Km} \mathrm{N}$. de Cariari, Finca/ E. Rojas, A. C. Tortuguero, Prov. Limón,/ COSTA RICA. $150 \mathrm{~m}$. Ene 1994, E. Rojas,/ L N 286000 567500 \#2549”, CRI001 856377, CRI001 856322, both female (INBC 2); „Sector Cocori, $30 \mathrm{~km}$ al N. de Cariari, A. C./ Tortuguero, Prov. Limón, COSTA RICA./ 100 m. Feb 1994, E. Rojas, L N/286000_567500 \#2608”, CRI001 846598, female (JPPC); ,Sector Cerro Cocori, Fca./ de E. Rojas, $150 \mathrm{~m}$, Prov./ Limon, Costa Rica, E./ Rojas, [date],/ L-N-286000, 567500", with dates: Ago 1991, CRI000 581541, male, dissected (CMNC); Nov 1991, CRI000 525146, female (INBC); Dic 1991, CRI000 550464, female (INBC); Ene 1992, CRI000 549393, male (INBC); Ene 1992, CRI000 333317, female (INBC); „Sector Cerro Cocori, Fca./ de E. Rojas, 150 m, Prov./Limon, Costa Rica, [da/ te],/ E. Rojas/ L-N 286000, 567500", with dates: Oct 1992, CRI000 931790 , male (INBC); 26 jun a 16 jul 1992, CRI000 695476, CRI000 703586, both male (INBC 2); Oct 1992, CRI000 932142, male (INBC); 9 a 30 nov 1992, CRI000 899436, CRI000 899788, CRI000 894538, all female (INBC 3); „Sector Cerro Cocori, Fca/ de E. Rojas, Prov. Limon/ COSTA RICA, E. Rojas/ Abr 1991,/ L-N-286000, 567500”, CRI000 688371, female (INBC); „COSTA RICA, Prov. Alajuela, San/ Cristobal, 600-620 m, ABR 1998. F./ A. Quesada. L_N_318056_383200/ \#50700", CRI002 526253, male, dissected (JPPC), CRI002 526252, female (INBC); „Est. Magsasay, P.N./ Braulio Carrillo, $200 \mathrm{~m}$ / Prov. Here, COSTA RICA/ M. Barrelier, Ene 1991,/ LN-264600, 531100”, CRT000 064545, female (INBC); „Est. Hitoy Cerere, 100 m, R./ Cerere, Res. Biol. Hitoy Cerere,/ Prov. Limón, COSTA RICA. 20/ May-6 Jun 1993. G. Garballo./ L-N-184200, 643300”, CRI001 161779, female (INBC); „Sardinas, Barra del Colorado, Prov./ Limon, COSTA RICA. 15 m. 26 JUL/ 1995. F. Araya, L_N_291900_565900/ \#5338”, CRI002 209574, female (INBC); „COSTA RICA: Prov./ Heredia, F. La Selva/ $3 \mathrm{~km} \mathrm{~S} \mathrm{Pto.} \mathrm{Viejo/} 10^{\circ} 26^{\prime} \mathrm{N} 84^{\circ} 01^{\prime}$ W”, „28.vii.1982/ H.A. Hespenheide”, „SOLANUM", „116”, „A./ cleroides/ Ch", female (CHAH); „COSTA RICA/ Pr. Heredia/ Puerto Viejo/ Finca La Selva”, „R.J. Marquis, coll./ No. 114117 VIII 1982”, „Piper/ arieianum”, male (USNM); same label, except: No. 1134 15 VIII 1982, „Pentagonia/ donnell-smithii", "Voucher", „? n. sp. nr./ cleroides/ det. DR Whitehead”, male (USNM); "COSTA RICA: Prov. Heredia:/ 10km SE La Virgen,

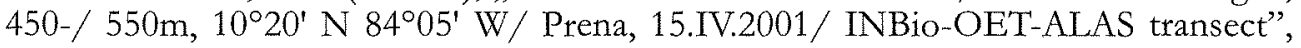
INB0003209987, INB0003209988, males (ALAS, JPPC); „Cartago/ Costarica”, „1913/ 29.", „Ambates/cleroides Champ.", „Staatl. Museum für/ Tierkunde Dresden”, female (SMTD). 
Description. Habitus: fig. 5, total length 4.8-6.6 $\mathrm{mm}$ (mean $=5.8, \mathrm{n}=30$ ). Head: piceous, scales white and light ochreous, moderately dense; frontal fovea absent, transition between head and rostrum slightly depressed; rostrum rufous, subcylindrical, slightly curved, laterodistally with white scales (males) or nude (females), dorsomedian carina distinct (males) or feeble (females), rostral length males 1.05-1.17x (mean=1.10, $\mathrm{n}=11$ ), females $1.11-1.25 \mathrm{x}$ (mean $=1.17, \mathrm{n}=19$ ) pronotal length, portion distal to antennal insertion males $0.37-0.40 \mathrm{x}$ (mean $=0.38, \mathrm{n}=11$ ), females $0.39-0.44 \mathrm{x}($ mean $=0.41, \mathrm{n}=19)$ total rostral length; antenna rufous, funicular segment 2 very slightly longer than 1 , antennal scrobe gradually descending and reaching ventral margin of rostrum before eye. Pronotum: piceous to black, scales black in frontal portion and white to ochreous in basal portion; pronotal length males $0.88-0.93 \mathrm{x}$ (mean $=0.91, \mathrm{n}=11$ ), females $0.88-0.94 \mathrm{x}$ (mean $=0.91$, $\mathrm{n}=19$ ) maximum width; pronotal width males $0.71-0.74 \mathrm{x}$ (mean $=0.73, \mathrm{n}=11$ ), females $0.70-0.75 \mathrm{x}$ (mean $=0.72, \mathrm{n}=18$ ) greatest elytral width, sexual dimorphism (gibbosity) indistinct; sides subparallel in basal half or slightly diverging to middle, then roundly nartowed and tubulate in front, disk strongly convex, punctate, intervals confluent, dorsomedian carina absent. Elytra: Basal half rufous with dark ochreous scales, caudal half piceous, with broad fascia of black scales bordered by portions of white to light ochreous scales, median fascia of white scales slightly oblique, not curved basally on interstria 2; elytral length $1.45-1.56 \mathrm{x}$ (mean $=1.51, \mathrm{n}=30$ ) width at humeri, sides gradually converging behind humeri, preapical callus moderately developed, striae distinct, interstriae 2-9 costate at least in caudal half. Legs: rufous, femora moderately expanded dorsoventrally, femoral tooth distinct, tibial margin ventrodistally with cluster of yellow hairs. Venter: rufous to piceous, flanks and sternite 4 with white to light ochreous scales; procoxae contiguous in both sexes. Male genitalia: anterior portion of aedeagus strongly curved ventrad, apodemes $2.7 x$ longer than body of aedeagus, aedeagal flagellum as long as apodemes, tapered basally in four claspers (fig. 18).

Plant association. This species was found in association with Pentagonia donnell-smithii (MARQuis 1, PRENA 4), at two occasions feeding while resting in holes made in leaves. Single observations were made also on Piper arieianum (MARQuIS) and Solanum sp. (HESPENHEIDE), but these associations are probably accidental.

Distribution. Pardisomus camotus occurs in Atlantic Costa Rica (fig. 28), with most records from elevations below $600 \mathrm{~m}$. The species is likely to be found in the neighboring regions of Nicaragua and Panama.

Specific epithet. The name amotus is a Latin participle meaning away from a place or area. It refers to the geographic separation of the species from $P$. cleroides.

Discussion. Pardisomus amotus is the Atlantic sibling species of the Pacific $P$. cleroides. Reasons for giving it full specific rank are 1) statistically significant difference in body proportion, 2) different color pattern, 3) different degree of sexual dimorphism, 4) different host plants and 5) allopatry. The showy color pattern derives from two black elytral maculae and a light colored circumferential line. Each of those elements merge transversely across the elytral suture. Male specimens of $P$. amotus and $P$. cleroides can be recognized by the presence of white scales apicad of the antennal insertion. 

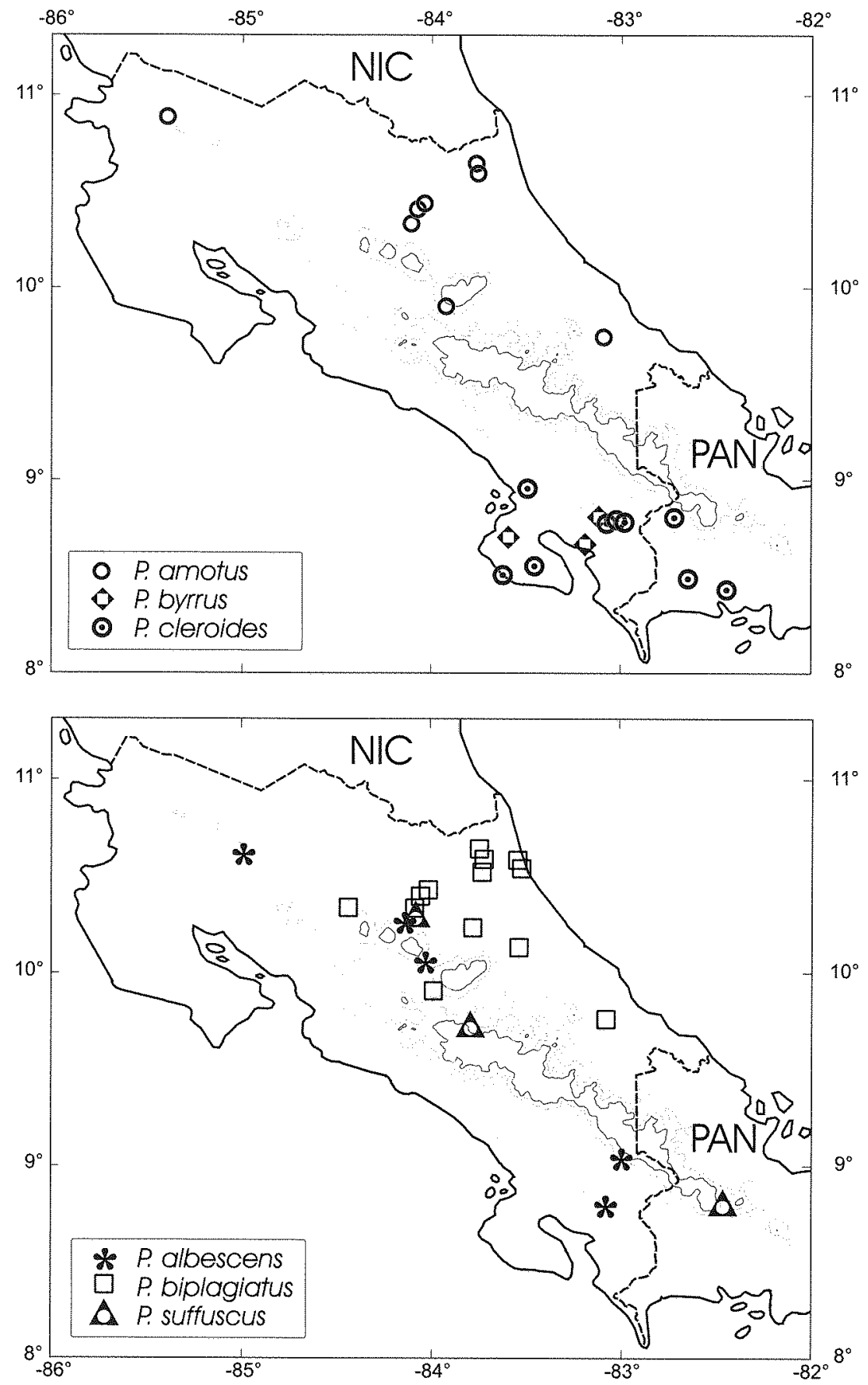

Fig. 28. Pardisomus. Map of Costa Rica showing the topographic relief $(1000,1500$ and $2000 \mathrm{~m})$ and the collecting sites of $P$. amotus, $P$. byrrus, $P$. cleroides (top), $P$. albescens, $P$. biplagiatus and $P$. suffuscus (bottom) 


\section{Pardisomus cleroides (CHAMPION), comb. n.}

Figs. 6, 7, 19, 28

Ambates cleroides CHAMPION, 1907: 170. Lectotype sex not determined, Panama, designated here, labeled: circular plate with red margin „Type”, „Bugaba/ 800-1500 ft [250-450 m]/ CHAMPION”, „B.C.A. Col. IV.5./ Ambates/ cleroides/ Champ." (BMNH). HuSTACHE, 1938 (cat.); BLACKWELDER 1947 (cat.); O'BRIEN \& WIBMER, 1982 (cat.). Paralectotypes 3 [CHAMPION, 1907: 170, cites another specimen from David, which I was unable to locate], designated here, same locality label as holotype (BMNH 2, USNMD.

Anambates cleroides (CHAMPION). CASEY, 1922: 7.

Embates cleroides (CHAMPION). AlONSO-ZARAZAGA \& LyAL, 1999: 93. (Embates Chevrolat, 1833 resurrected and synonymized with Ambates SCHÖNHERR, 1836)

Diagnosis. Pardisomus cleroides differs from P. amotus sp. n. (described above) as follows:

1) Elytra shorter and more broadly triangular (fig. 6), length 1.37-1.47x (mean=1.43, $\mathrm{n}=30$ ) width at humeri, width $1.30-1.48 \mathrm{x}$ (mean $=1.39, \mathrm{n}=30$ ) maximum pronotal width.

2) Pronotum proportionately larger in both sexes, strongly gibbous in males.

3) Basal sclerite L-shaped, transition to aedeagal flagellum abrupt (fig. 19).

4) Median elytral fascia of white scales curved basally on interstria 2 (fig. 6). Dorsal vestiture of white scales on head and rostrum very dense, imbricate.

Plant association. I.A.CHACÓN (INBio, pers. comm.) observed adult specimens of $P$. cleroides in Fila Cruces, Puntarenas, feeding on a species of Pentagonia with lobed leaves. The description may apply to $P$. lobata or $P$. tinajita.

Distribution. Pardisomus cleroides occurs on the Pacific side of the Cordillera de Talamanca, at elevations below $1500 \mathrm{~m}$ (fig. 28).

Material examined. A total of 39 specimens (14 males, 14 females, 11 not sexed) was examined from the following locations. COSTA RICA. Puntarenas: Peninsula de Osa, P.N. Corcovado, Est. Sirena, 0-100 m (INBC 16, JPPC 2); Peninsula de Osa, Palmar Sur, $20 \mathrm{~m}$ (INBC); Peninsula de Osa, Fila Matahambre, $300 \mathrm{~m}$ (INBC); Fila Cruces, Fca. Ilama, $1200 \mathrm{~m}$ (INBC 13); Fila Cruces, Laguna Gamboa, $1400 \mathrm{~m}$ (INBC); San Vito, Wilson Botanical Garden, 1100 m (CWOB). PANAMA. Chiriquí: Bugaba, 300$500 \mathrm{~m}$ (BMNH 3, USNM); 11 mi E Rio Sereno, $1000 \mathrm{~m}$ (CWOB).

Discussion. See under $P$. amotus

\section{References}

ALONSO-ZARAZAGA, M. A. \& LyAL, C. H. C. 1999: A world catalogue of families and genera of Curculionoidea (excepting Scolytidae and Platypodidae). - EntomoPraxis S.C.P., Barcelona, 316 pp.

BLACKWELDER, R. E. 1947: Checklist of the Coleopterous insects of Mexico, Central America, the West Indies, and South America. Part 5. - Bull. U.S. Natl. Mus., 185: 765-925.

CASEY, T. L. 1922: Studies in the Rhynchophorous subfamily Barinae of the Brazilian fauna. - Mem. Coleopt., 10: 1-520.

ChampIon, G. C. 1907: Biologia Centrali-Americana. Insecta. Coleoptera IV.5, pp. 137-240. 
Chevrolat, A. 1833: Coléoptères du Mexique, fasc. 1. - Strasbourg [1834]. 25 pp. [pages not numbered].

DEsBrochers DES LOGES, J. 1906: Études sur les Curculionides exotiques et descriptions d'espèces inédites. - Ann. Soc. Entomol. Belg. 50: 355-372.

DESBROCHERS DES LOGES, J. 1907: Corrections et additions suivantes à faire à son mémoire sur les Cholides. - Ann. Soc. Entomol. Belg. 51: 6.

FAUST, J. 1892: Reise von E. Simon in Venezuela. Curculionidae. - Stett. Entomol. Ztg. 53: 1-44.

HELLER, K. M. 1908: Synonymische und andere auf die Systematik bezügliche Notizen. - Dtsch. Entomol. Zeitschr., 1907 (1908), 58-59.

HUStAChe, A. 1938: Curculionidae, Barinae. - In: Schenkung, S. Coleopterorum Catalogus. Pars 163. Verlag für Naturwissenschaften, W. Junk, "s-Gravenhage, pp. 1-219.

Hustache, A. 1950: Nouveaux Barinae Sud Américains. Première partie - Ambatini, Peridinetini, Pantotelini, Cyrionichyna [sic] et Optanini [sic]. - Bol. Mus. Nac., Rio de J., N. Ser., Zool., 1949 (1950), 95: $1-55$.

KIRSCH, T. 1875: Beiträge zur Kenntniss der Peruanischen Käferfauna auf Dr. Abendroth's Sammlungen basiert. - Dtsch. Entomol. Zeitschr. 19 (2): 241-304.

KUschel, G. 1958: Neotropische Rüsselkäfer aus dem Museum G. Frey (Col. Curcul.). - Entomol. Arb. Mus. Frey 9 (3): 750-798.

LACORDAIRE, T. 1866: Histoire naturelle des insectes. Genera des Coléoptères ou exposé méthodique et critique de tous les genres proposés jusqu'ici dans cet ordre d'insectes. - Roret, Paris. Vol. 7, pp. 1-620.

MARquis, R. J. 1991: Herbivore fauna of Piper (Piperaceae) in a Costa Rican wet forest: diversity, specificity, and impact. - In: PRICE, P. W., LEWInsohn, T. M., FERNANDES, G. W. \& BENSON, W. W.: Evolutionary ecology in tropical and temperate regions, pp. 179-208.

MAY, B. M. 1994: An introduction to the immature stages of Australian Curculionoidea. - In: ZINMERMAN, E. C. Australian Weevils Vol, II, pp. 365-728.

O'BRIEN, C. W. \& WIBMER, G. J. 1982: Annotated checklist of the weevils (Curculionidae sensu lato) of North America, Central America, and the West Indies (Coleoptera: Curculionidae). - Mem. Am, Entomol. Inst., 34, i-ix, 563 pp.

PASCOE, F. P. 1889: On the weevil genus Centrinus and its allies. - Ann. Mag. Nat. Hist., ser. 6, 4: 321-330.

SCHÖNHERR, C. J. 1836: Genera et species curculionidum cum synonymia hujus familiae. - Roret, Paris; Fleischer, Lipsiae. Vol. 3 (1), pp. 1-505.

Voss, E. 1954: Curculionidae (Col.). - In: TITSCHACK, E. Beiträge zur Fauna Perus IV, pp. 193-376.

\author{
Author's address: \\ JENS PRENA \\ Mozartstr. 24 \\ D-18069 Rostock \\ Germany \\ e-mail: baridinae@gmx.de
}

